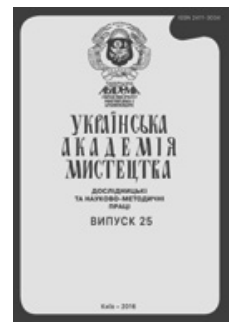

№27 (2018) стор. 235-243

The National Academy of Fine Arts and Architecture

Ukrainian Academy of Fine Art. Research and Methodology Papers

ISSN 2411-3034

Website: http://naoma-science.kiev.ua/

УДК 7:005.745

ORCID 0000-0003-2261-0195

DIO: https://doi.org/10.33838/naoma.27.2018.235-242

\title{
Олександр Храпачов
}

стариий викладач кафедри живопису і композиції НАОМА

krapathev@ukr.net

\section{РОЛЬ ТВОРЧИХ СИМПОЗІУМІВ У ФОРМУВАННІ ХУДОЖНИКА}

Анотація. У статті висвітлюються загальні тенденції розвитку творчих осередків та їхнє значення у формуванні творчої особистості.

Ключові слова: мистецттво, творчість, пленер, симпозіум.

\section{РОЛЬ ТВОРЧЕСКИХ СИМПОЗИУМОВ В ФОРМИРОВАНИИ ХУДОЖНИКА.}

Александр Храпачев

Аннотация: в данной статье освещчаются общче тенденции развития творческих групп и их значение в формировании творческой личности.

Ключевые слова: искусство, творчество, пленэр, симпозиум.

\section{ROLE OF CREATIVE SYMPOSIA IN FORMING THE ARTIST.}

Oleksandr Khrapachov

Annotation. The cooperative creative work in the art has always facilitated the creation of artistic works of high quality and required this process to be organized in a certain way, from both material and ideological perspective. There are plenty of creative symposia and plein-airs in Ukraine. Therefore, in our opinion, it is important to generally characterize this process and to reveal trends and prospects for creative projects in the modern artistic world.

The plein-air is instructive from both theoretical and practical perspective. Exactly on the plein-airs an artist experiences a first shock from what he has seen in the nature; this sinks deep into the mind and nourishes both studies from nature and the whole process of making of a painting in the art studio.

The plein-air gives the freshness of light perception to the artist; colors become clear, lightful and transparent. Each hue brings the artist curious brain to a big secret hidden in the nature. Its motifs are inexhaustible for learning its each fragment and manifestation. The life, country and its history give all the most beautiful things to the artist. In most cases impressions got on the plein-air are brought to the art studio and generalized paintings are made exactly there. And this is not a wave landscape portrait but the generalized image of Ukraine.

Fundamental plein-airs and symposia among creative teams are organized with the support of the government or private organizations that feel involved in the process of creating a culture. Organizers set a main theme of the symposium, cover the accommodation and meal as well as tour expenses, finance a report exhibition of the creative team, catalog etc.

Artistic projects are sponsored by large corporations or business structures as well as by diplomatic corps as art patrons which can crank them up a notch in the society not thanks to the economic basis but thanks to the art. We 
can see how the Ukrainian business intellectuals grow, intellectuals that understand the role of arts patronage well by following the example of their high-ranking foregoers from the beginning of the XX century.

Round tables at symposia offer an opportunity to discuss prospects of the modern art and its tasks; such discussions are the anvil upon which the spark of truth is struck.

In artistic groups the inner psychological space is organized more quickly: What is meant here is the inner world of each artist. In the environment with the certain spacing it is possible to simulate individual features of perception of reality, response and life style, i.e. life journey.

The Ukrainian folk artist Vasyl Perevalsky emphasizes that all artists are different. Not everybody is able to work in the creative team. It all depends on psychological features of the artist. There are artists who, when making a painting, work more effectively in their art studios by going deep into their ideas, other world and logic of perception.

In the opinion of the Ukrainian famous painter Vasyl Hurin, "a thematic painting must be unique and not repeat the past things. It must maturate and naturally go up".

Artistic symposia and plein-airs play a major role in forming the modern artistic idea. By participating directly in symposia the artist can understand regularities of individual life, discover his reserves and thus change his behavior by stimulating development and creating a project of life.

Key words: art, creative work, plein-air, symposium.

Постановка проблеми. Із кожною зміною мистецької епохи змінюються мистецькі вимоги для сучасників, враховуючи досвід минулих поколінь. Колективна творча робота у мистецтві завжди була актуальною при створенні якісного мистецтва і завжди вимагала певної організації цього процесу в матеріальному та ідейному сенсі. В Україні відбувається величезна кількість творчих пленерів та симпозіумів. Отож, останнім часом, постала велика потреба у загальній характеристиці та виявленні тенденції і перспектив проведення творчих проектів у сучасному мистецькому світі.

Актуальність дослідження. Зведення сучасних мистецьких процесів до об’єктивної оцінки у порівнянні $з$ історичним досвідом $є$ актуальним для подальшого переосмислення проблеми формування творчих осередків у академічній сучасній мистецькій освіті. За часи незалежності України було проведено сотні мистецьких симпозіумів та пленерів, але точної статистики цих заходів не здійснювалося. Близько 75 \% відсотків творчих проектів загалом не були зафіксовані документально у періодичних виданнях, пресі, каталогах, телебаченні тощо.

Тема дослідження безпосередньо пов'язана із методичними науковими програмами кафедри живопису і композиції Національної академії образотворчого мистецтва і архітектури (НАОМА).

Аналіз останніх досліджень та публікацій свідчить про недостатню об’єктивну оцінку цього питання. Мистецькі симпозіуми в наукових та періодичних виданнях висвітлюються з точки зору узагальненої методичності, мистецькі проекти без прив'язки до загального мистецького середовища України. Неодноразово писали про симпозіуми та пленери О. Федорук, В. Петрашик, О. Авраменко, О. Соловей, Н. Сухоліт та інші. Переважно ці статті друкувались в періодичних журналах: «Образотворче мистецтво», «Музейний провулок», «Антиквар», «Українське мистецтво», «FAINE ART» та інші.

Зазначення невирішених раніше частин загальної проблеми, яким присвячусться стаття. Автор приділяє увагу взаємозв'язкові творчих мистецьких уподобань в історичному аспекті.

Новизна наукового дослідження полягає у намаганні надати об'єктивну оцінку творчих формувань в Україні.

Методичне або загальнонаукове значення авторських розробок зводиться до використання матеріалу у мистецькій освіті з академічного живопису.

В усі часи мистецтво проявлялось в суспільстві через індивідуальне та суспільне. Колективна творчість часто переважала над індивідуальністю. Тому в історії мистецтва ми спостерігаємо великі сплески творчої активності саме під час формування творчих об’єднань (Греція, Відродження, «барбізонці», імпресіоністи, передвижники), які представляли потім, як майбутні школи. 
Великий вплив на формування власної живописної мови майстра справляють творчі поїздки. Спільні зустрічі з наставниками, походи на пленери старших та молодших, так звані «посиденьки», на яких вони багато розмовляють, обговорюють картини, сперечаються, - все це формує якусь живу атмосферу. (Кашшай 81)

Одним із видів колективної творчої роботи в сучасному світі є проведення пленерів та симпозіумів. «Вони привертають величезну увагу не тільки творчої інтелігенції». (Федорук, Сказка 6) Колективна енергія спричиняє більш продуктивному результату. Художники надихають один одного, «обмінюючись враженнями і досвідом» (Гужва 158). «Глибоке занурення в нове середовище» (Стратійчук 92) активізує «митців до напруженої, самовідданої праці» (Сухоліт, Plener 2), вони розкривають для себе нові грані в українському та світовому мистецтві.

Пленер повчальний - теоретично і практично (Федорук, Школа 92).

На пленері перше потрясіння від побаченого в природі стає пережитим, западає в душу, живить як натурні етюди, так і увесь процес визрівання картин у майстерні. (Федорук, Два крила 63-4)

Пленер дає художникові свіжість світосприйняття, його кольори стають дзвінкими, світлоносними й прозорими». (Гурін 13)

Кожен відтінок наближає допитливий розум митця до великої, схованої в природі таїни. Мотиви природи «невичерпні для пізнання в кожному своєму фрагменті й вияві» (Толстова 33 ).

Усе найпрекрасніше дарують художникові життя, рідна земля та їі історія. (Голембиевская 85)

Зафіксовані на пленері враження найчастіше переносяться до студій - і вже тут «створюються картини широкого узагальнення, вже не хвилевий портрет ландшафту, а узагальнений образ України». (Калинець 49)

Пленери в Україні переважно відбуваються в період цвітіння навесні і під час золотої осені. В ці пори року можуть відбуватись до 20 пленерів водночас. По-перше, це періоди року, коли не дуже спекотно від сонця і не дуже холодно, як взимку, i художник почувається комфортно. По-друге, природа розкриває свої барви на дуже короткий термін. Навіть для абстракціоністів, які наче й не пов’язані
3 натурою, ці стани природи цікаві, як творчі варіації, які підказує сама земля.

Організація фундаментальних пленерів і симпозіумів у творчих осередках не відбувається хаотично. Потрібна підтримка держави або приватних організацій, «має бути присутнє відчуття власної причетності до процесу творення культури». (Колісник 95)

Організатори обирають загальну тему симпозіуму, фінансують проживання, харчування, екскурсії по місцевості, готують звітні виставки творчої групи, каталог тощо.

Загалом перша «ідея сумісної виїзної творчої практики набула найбільшого розвитку в другій половині XIX ст. у імпресіоністів». (Сухоліт, Дубенський 160) Вони займались безпосередньо пленерним живописом. Але якщо говорити про сьогодення, маємо зауважити, що у сучасному мистецькому світі переважають симпозіуми. Тобто художники також продовжують організовано виїджати творчими групами, але не обов'язково писати на відкритому повітрі пейзаж - акцент переноситься на індивідуальне творче самовираження. Відбуваються навіть скульптурні симпозіуми. Завдяки вивченню історії зображуваного місця та різним методам творчого самовираження з'являються дуже «цікаві творчі ідеї завдяки новим мистецьким силам» (Алексєєва 30). Наприклад, абстракціоністи абсолютно інакше підходять до творчого самовираження, ніж реалісти і саме в цьому полягає сенс симпозіумів. Нині завдання полягає в тому, щоб, наприклад, «живописці висловили власне сприйняття, спіймали хвилю» (Калита 78) та «розуміння природного й культурного світу» (Авраменко, Гурзуфські 119).

Якщо згадати історію започаткування ідеї поєднання різних мистецтв на території України, то корені ідуть від заснування Спілки художників 1938 року. Ідея створення Спілки державою, звичайно полягала у контрольованому процесі виконання державної соціалістичної ідеології у мистецтві. Соцреалізм виник, як закономірний результат суспільних процесів в культурі $20-x$ років; то був задум деякої філософії мистецтва, зобов'язаної перейти у норму, обов'язкову для всіх радянських художників (Булавка 44). Підтримувались тільки ті художники, які дотримувались «правильного» 
мистецтва. Але були і величезні позитивні якості державної підтримки, коли будувались майстерні, виставкові зали і подібне.

Досвід «існування Спілки упродовж 1938-1953 років» (Соловей 19) виявив недостатність для повноцінного існування мистецького середовища тільки проведенням всеукраїнських та всесоюзних виставок, постало питання подальшого розвитку художників на грунті самої Спілки, через обмін досвідом між художниками різних міст та країн Радянського Союзу. Почали будуватись будинки творчості, «в яких гуртувались майстри і молоді художники» (Вторушна 31). Задля сприяння утвердження високих моральних принципів та духовного розвитку народів, створювались міжнародні будинки творчості: у Седневі в Україні 1964 р., Сенежі в Росії, Сєвані у Вірменії та інші. Ці бази будувались майже водночас і мають подібну архітектуру. Ідея сучасного симпозіуму зародилась, мабуть, саме тоді.

Щодо сучасного стану Спілки - вона від держави нічого не отримує, а навпаки, намагається зберегти те, що залишилось. Насправді нерухоме майно об'єднує художників і не пускає на самоплив художні процеси в Україні, зберігаючи державність у мистецтві, хоча з боку держави ліквідовані пільги для творчих об'єднань України, які надавались десятиріччями. Будь-яка країна дуже залежна від мистецтва - воно може ії підняти, або навпаки принизити. Зараз ми переживаємо часи становлення української незалежності, і поки що державі не вистачає приділити достатньо часу фундаментальному мистецтву. Тому сьогодні Національна Спілка художників України самотужки відіграє велику роль у формуванні сучасної художньої інтелігенції.

Сьогодні в організації симпозіумів і пленерів неабияке значення мають приватні організації: галереї, готельні комплекси, банки і т.д. (Дорохова 94); вони сприяють належному фінансуванню, формуванню певної мистецької думки в Україні. Перейнявши ініціативу, приватні організації вкладають власні кошти і хочуть бачити в цьому сенс, тому й вимоги до художників, відповідно, інакші ніж у 1960-1980 роки, - митці безкоштовно проживали два місяці на творчій базі, їм надавали фарби, полотна, харчували і т.д.; художники залишали тільки одну картину за цей термін.
Зацікавлення приватних структур в організації творчих процесів виникає в першу чергу для розширення світогляду, задля морального відпочинку від своєї щоденної роботи, бажання реалізувати свої естетичні ідеї за допомогою спілкування через мистецтво. Під час та після проведення творчих з'їздів організатори отримують величезний емоційний підйом, їм хочеться творити, розвиватись, з'являється більша цікавість до навколишнього світу. Спілкування не просто 3 художніми творами, а безпосередньо з самими художниками. А під час створення цих полотен, допомагати одержати більше вражень для галеристів, ніж просто проведення виставки.

Великі корпорації, або бізнес-структури, дипломатичні корпуси фінансують мистецькі проекти у якості меценатів з метою поставити себе на щабель вище у суспільстві, коли діалог ведеться не суто економічний, а на фундаменті мистецтва. На наших очах виростає прошарок української бізнесової інтелігенції та меценацтва, які беруть приклад зі своїх попередників-достойників початку XX ст. (Петрашик 75).

Мистецтво завжди залежало від мецената. Меценацтво - це фінансування створення справжнього мистецтва для підняття духовного рівня усього суспільства. Якби не було Терещенка або Третьякова, не було б справжніх творів того періоду передвижників. Коли пішов з життя Третьяков, їхне мистецтво пішло на згасання, на зниження до світогляду колекціонерів того часу.

У часи соціалістичного реалізму рівень виконання державного замовлення завжди контролювала комісія від Міністерства культури, в яку входили провідні художники того часу. Саме завдяки такому колективному контролю, а не однісї людини, світ побачив картини дуже високого рівня, які досі залишаються класикою українського і всесвітнього мистецтва.

Василь Іванович Гурін згадував:

Державна комісія по декілька, іноді десятки разів, не допускала картину навіть через легку незавершеність. Але платили відповідно. Картина писалась рік, за цей рік можна було купити квартиру, наступний машину, далі - дачу. У вільний час від державного замовлення можна було займатись творчістю, виставлятись на всеукраїнських та все- 
союзних виставках, на яких державна комісія закуповувала твори до музеїв. (10)

Замовник сьогодні переважно приватний, тому і стан мистецтва змінився, його рівень не керується державою. На жаль, поступово зникає потреба в історичній картині, яка є відбитком історії нашого народу. Адже приватний замовник переважно орієнтується на модні течії і уподобання, які що п’ять років змінюються, і минуле мистецтво стає нікому не потрібне.

Держава повинна створити умови для розвитку професійного мистецтва, забезпечити йому академічну свободу і звільнити від ринкового волюнтаризму. Контент у галузі науки і мистецтва має враховувати національні інтереси в ім'я національної безпеки (Федорук, Слово 5). Але ж насправді не відбувається навіть загального реєстру ініціативних творчих груп на території України, не кажучи вже про закордонні осередки творчих формувань. Загалом, фундаментальна творча ініціатива повинна підтримуватись дотаціями з боку держави, підвищуючи рівень українського мистецтва, аби гідно представляти його на світовому рівні. Чомусь в Європі, Китаї, Америці ці фонди є, котрі підтримують навіть закордонну творчу ініціативу, збагачуючи свою. Завдяки їм відбувається діалог між мистецькими вишами різних держав. Ще у Греції, в IV ст. до н.е., формувалась своєрідна система виховних заходів, за допомогою якої передбачалося укріплювати і покращувати державу (Ольховська 89).

Переважно цю ініціативу беруть у свої руки приватні галереї в Україні. Але не всі вони дотримуються гуманістичної ідеї розвитку суспільства, що йде у протиріч із поняттям державності.

Насправді в будь-якій величезній імперії або міцній державі мистецтво займало провідну роль. Оточуючи людину гармонійним мистецтвом, вона несе це в свою сім'ю, а сім'я, як ланка суспільства, інакше, гуманістично ставиться до свого осередку, і поступово підвищується рівень державного мислення. Тому, розуміючи це, в сильних країнах цьому приділяється величезна увага.

Мистецтво - це метод світогляду. Художник це людина, яка постійно себе шукає. Тому ми знаємо про різні творчі періоди у митців. Вони замислювались - навіщо робити те, що досконало вже зробив не один раз? Тобто не перетворювали мистецтво на ремесло.

Художник не повинен залежати від кількості фарби у нього. Коли фарби відра, кілометри полотна, - він експериментує з ідеями, шукає. Щось не сподобалось - викинув, записав. Тоді з'являється справжнє мистецтво, з'являються цікаві, не завчені твори.

На симпозіумах влаштовуються круглі столи, відбувається обговорення мистецтва мистецтвознавцями та художниками, обговорюються перспективи сучасного мистецтва та його завдання, i в цьому діалозі народжується істина. Кожен з’їзд художників сприймається індивідуально, він залишається тільки в спогадах самих художників, якщо нема мистецтвознавців, які розставлять акценти у мистецтві вже сьогодні, а не через сто років. Вони відіграють важливу роль у формуванні сучасної мистецької думки та задають тон на самих симпозіумах, гармонійно працюючи $з$ художниками. Мистецтвознавство розкриває мистецтво для глядача.

Коли художник створює щось нове у мистецтві, воно не завжди зрозуміле сучасникам. Яскраві приклади - імпресіоністи, супрематизм і т.д. Роль мистецтвознавця - вчасно побачити новий прояв i розгорнути його для глядача. Художник завжди в пошуку нового й необхідного. Зрозуміло, воно може бути добре забутим старим, але потрібним сьогодні. Художник, як душа суспільства, відчуваючи тонкі еманації простору, фіксує його на полотні.

Зазвичай діалог художників на симпозіумах відбувається як взаємообмін мистецьких шкіл, бо «національна мистецька освіта - це основа основ мистецького руху, розвитку кращих творчих ініціатив» (Стороженко 59). Наші національні київська, харківська, львівська, ужгородська академії готують мистецькі кадри високого професійного рівня, які задовольняють найвибагливіші смаки.

Існують не тільки традиції художньої творчості, а й «традиції школи, педагогічний досвід - як національні здобутки - й основним критерієм тут має бути високий рівень художника-професіонала як творця майбутнього мистецтва» (Чепелик 8). На грунті мистецьких груп відбувається взаємообмін досвідом викладачів різних мистецьких закладів. Наприклад, київська і харківська школа тяжіють до реалістичного мистецтва, а львівська 
i ужгородська - до декоративно-ужиткового. Кожен із учасників симпозіумів відчуває і позиціонує себе художником, «не зациклюючись на певному виді чи жанрі, тим паче на техніці» (Авраменко, Феномен 17).

У мистецькому колективі швидше відбувається визначення організації внутрішнього психологічного простору, тобто власного внутрішнього світу. Це важливо, оскільки «творчим особистостям досить часто властиве відчуття позбавленості своїх меж, а феноменологічно їх вважають потерпаючими від надлишку обмежень» (Сісецький 79). У середовищі $з$ певним просторовим вирішенням можливе моделювання особистісних особливостей, способу сприйняття дійсності, стилю реагування і життя, тобто життєвого шляху.

Василь Перевальський зауважує, що всі художники різні. Не кожен спроможний працювати в осередку творчої групи. Це «залежить від його психологічних властивостей» (Коляденко 78). С художники, які, навпаки, краще працюють, зачинившись в майстерні, поступово заглиблюються в свої ідеї, переживання, в інший світ та логіку сприйняття, створюючи картину.
Василь Гурін казав: «Тематична картина має бути оригінальною, не повторювати того, що вже було. Вона повинна визріти, природно вибухнути. Тоді це справді буде картина, адже хвилюватиме те, що схвилювало самого художника. Штучно вигадати вартий уваги твір не можна» (Гурін 15).

Головні висновки. Мистецькі симпозіуми та пленери відіграють величезну роль у формуванні сучасної мистецької думки. Безпосередньо для художника, при участі у симпозіумах, осягаються закономірності індивідуального життя, виявляються резерви особистості, що дозволяє змінювати їі поведінку, стимулювати розвиток творчості і створювати життєву перспективу. Творча колективна робота дозволяє досліджувати свій внутрішній процес шляхом активної уяви чи візуалізації, зміцнювати і збагачувати емоційні ресурси та комутативні можливості, тренувати здатність до мобілізації життєвого досвіду, розвивати саморегуляцію, збагачувати власне життя новими позитивними переживаннями.

Перспективи використання результатів дослідження. Дане дослідження має методичний характер при формуванні творчих груп та осередків.

\section{Цитовані праці}

Авраменко, Олеся. «Гурзуфські лани назавжди». Українське мистецтвво 7 (2012): 118-127. Друк.

Авраменко, Олеся. «Феномен київської школи: генерація мистців «епохи змін». Образотворче мистеитвво 2 (86) (2013): 16-17. Друк.

Алексєєва, Оксана. «Подорожні під хортицьким небом». Артанія 4 (17) (2009): 30-33. Друк.

Булавка, Людмила. Социалистический реализм: превратности метода. Философский дискурс. Москва: Культурная революция, 2007. Печать.

Вторушна, Марія. «Рецептивність кожного - зона майстерності». Образотворче мистецтво 3(87) (2013): 28-31. Друк.

Голембиевская, Татьяна. «Все самое прекрасное дарит художнику жизнь». Банкиръ 1 (35) (2011): 84-87. Печать.

Гурін, Василь. «Крим для українських художників - як Франція». Образотворче мистецтво 3 (87) (2013.): 10-15. Друк.

Гужва, Олена. «Мистецтво - спільна мова двох культур». Образотворче мистецтво 3 (71) (2009): 158. Друк.

Дорохова, Элина. «Инвестиции в искусство - новый поход в управлении капиталом». BIRUCHIY 1 (2014): 92-96. Печать.

Калинець, Ігор. «Країна, повита красою». Образотворче мистецзтво 3-4 (2000): 49. Друк.

Калита, Татьяна. «Моя задача - открывать миру наших художников». Антиквар 11-12 (87) (2014): 75-81. Печать.

Кашшай, Олена. «Антон Кашай». Образотворче мистецтво 2 (2011): 80-82. Друк.

Колісник, Прокіп. «Поташнянський «барбизон»». Артанія 4 (17) (2009): 94-96. Друк. 
Коляденко, Наталія. «Роль творчості у формуванні особистості й проблеми самовираження в мистецтві». Українська академія мистецтва : дослідн. та наук.-метод. пр. 12 (2005): 78-82. Друк.

Ольховська, Олена. «До історії освіти і становлення університетських центрів Свропи». Українська академія мистеитвв: дослідн. та наук.-метод. пр. 12 (2005): 88-94. Друк.

Петрашик, Володимир. «Роль сучасного колекціонера в Україні». Образотворче мистецтво 2(103) (2018): 74. Друк.

Сісецький, Андрій. «Інтегративний образ у структуруванні внутрішнього психологічного простору творчої особистості». Українська академія мистеитв : дослідн. та наук.-метод. пр. 13 (2006): 79-82. Друк.

Соловей, Олесь. «Київська школа». Образотворче мистецтво 2 (86) (2013): 19. Друк.

Стороженко, Микола. «Україна досі є могутнім джерелом «постачання» наших митців в інші культури». FAINE ART 3 (2008): 55-59. Друк.

Стратийчук, Иванна. «Живописные сезоны в «Мистецькому маєтку «Ставки». Антиквар 3-4 (89) (2015): 86-96. Печать.

Сухоліт, Наталія. «Дубенський замок. Живописний пленер». Українське мистецтво 5-6 (2010): 160-161. Друк.

Сухоліт, Наталія. Plener opanyi Gniew 2014: Кат. вист. Київ. 2016. Друк.

Толстова, Леся. «Талант самоцвітний: Киріак Костанді». Музейний провулок 1(5) (2006): 32-41. Друк.

Федорук, Александр. Сказка десятого пленэра: Альбом. Севастополь, 2007. Печать.

Федорук, Олександр. «Два крила Таланту. Графіка Олекси Захарчука». Музейний провулок 2 (4) (2005): 62-67. Друк.

Федорук, Олександр. «Слово редактора». Образотворче мистещтво 2 (103). (2018): 2-5. Друк.

Федорук, Олександр. «Школа, яка постійно оновлюється». Образотворче мистеитво 3-4 (2000): 92-96. Друк.

Чепелик, Володимир. «Попереду - тільки праця! Іншого не дано!» Образотворче мистеитво 2 (86) (2013): 6-8. Друк.

\section{References}

Avramenko, Olesia. «Hurzufski lany nazavzhdy». Ukrainske mystetstvo 7(2012): 118-127. Druk.

Avramenko, Olesia. «Fenomen kyivskoi shkoly: heneratsiia mysttsiv «epokhy zmin». Obrazotvorche mystetstvo 2 (86) (2013): 16-17. Druk.

Aleksieieva, Oksana. «Podorozhni pid khortytskym nebom». Artaniia 4 (17) (2009): 30-33. Druk.

Bulavka, Lyudmila. Sotsialisticheskiy realizm: prevratnosti metoda. Filosofskiy diskurs. Moskva: Kulturnaya revolyutsiya, 2007. Pechat.

Vtorushna, Mariia. «Retseptyvnist kozhnoho - zona maisternosti». Obrazotvorche mystetstvo 3(87) (2013): $28-31$. Druk.

Golembievskaya, Tatyana. «Vse samoe prekrasnoe darit hudozhniku zhizn». Bankir' 1 (35) (2011): 84-87. Pechat. Hurin, Vasyl. «Krym dlia ukrainskykh khudozhnykiv - yak Frantsiia». Obrazotvorche mystetstvo 3 (87) (2013.): 10-15. Druk.

Huzhva, Olena. «Mystetstvo - spilna mova dvokh kultur». Obrazotvorche mystetstvo 3 (71) (2009): 158. Druk.

Dorohova, Elina. «Investitsii v iskusstvo - novyiy pohod v upravlenii kapitalom». BIRUCHIY 1 (2014): 92-96. Pechat.

Kalynets, Ihor. «Kraina, povyta krasoiu». Obrazotvorche mystetstvo 3-4 (2000): 49. Druk.

Kalita, Tatyana. «Moya zadacha - otkryivat miru nashih hudozhnikov». Antikvar 11-12 (87) (2014): 75-81. Pechat.

Kashshai, Olena. «Anton Kashai». Obrazotvorche mystetstvo 2 (2011): 80-82. Druk.

Kolisnyk, Prokip. «Potashnianskyi «barbyzon»». Artaniia 4 (17) (2009): 94-96. Druk.

Koliadenko, Nataliia. «Rol tvorchosti u formuvanni osobystosti y problemy samovyrazhennia v mystetstvi». Ukrainska akademiia mystetstva : doslidn. ta nauk.-metod. pr. 12 (2005): 78-82. Druk. 
Olkhovska, Olena. «Do istorii osvity i stanovlennia universytetskykh tsentriv Yevropy». Ukrainska akademiia mystetstva: doslidn. ta nauk.-metod. pr. 12 (2005): 88-94. Druk.

Petrashyk, Volodymyr. «Rol suchasnoho kolektsionera v Ukraini». Obrazotvorche mystetstvo 2(103) (2018): 74. Druk.

Sisetskyi, Andrii. «Intehratyvnyi obraz u strukturuvanni vnutrishnoho psykholohichnoho prostoru tvorchoi osobystosti». Ukrainska akademiia mystetstv : doslidn. ta nauk.-metod. pr. 13 (2006): 79-82. Druk.

Solovei, Oles. «Kyivska shkola». Obrazotvorche mystetstvo 2 (86) (2013): 19. Druk.

Storozhenko, Mykola. «Ukraina dosi ye mohutnim dzherelom «postachannia» nashykh myttsiv v inshi kultury». FAINE ART 3 (2008): 55-59. Druk.

Stratiychuk, Ivanna. «Zhivopisnyie sezonyi v «Mystetskomu maietku «Stavky». Antikvar 3-4 (89) (2015): 86-96. Pechat.

Сухоліт, Наталія. «Дубенський замок. Живописний пленер». Украӥнське мистецтво 5-6 (2010): 160-161. Друк.

Sukholit, Nataliia. Plener opanyi Gniew 2014: Kat. vyst. Kyiv. 2016. Druk.

Tolstova, Lesia. «Talant samotsvitnyi: Kyriak Kostandi». Muzeinyi provulok 1(5) (2006): 32-41. Druk.

Fedoruk, Aleksandr. Skazka desyatogo plenera: Albom. Sevastopol, 2007. Pechat.

Fedoruk, Oleksandr. «Dva kryla Talantu. Hrafika Oleksy Zakharchuka». Muzeinyi provulok 2 (4) (2005): $62-67$. Druk.

Fedoruk, Oleksandr. «Slovo redaktora». Obrazotvorche mystetstvo 2 (103). (2018): 2-5. Druk.

Fedoruk, Oleksandr. «Shkola, yaka postiino onovliuietsia». Obrazotvorche mystetstvo 3-4 (2000): 92-96. Druk. Chepelyk, Volodymyr. «Poperedu - tilky pratsia! Inshoho ne dano!» Obrazotvorche mystetstvo 2 (86) (2013): 6-8. Druk.

Подано до редакизї 31.08.2018

Рецензенти:

Петрашик В. I. - кандидат мистецтвознавства, доцент;

Ковальчук О. В. - кандидат мистецтвознавства, доцент. 